\title{
Somaclonal Variation of Coreopsis Regenerated from Leaf Explants
}

\author{
Brian W. Trader, ${ }^{1}$ Hope A. Gruszewski, Holly L. Scoggins, and \\ Richard E. Veilleux \\ Department of Horticulture, Virginia Polytechnic Institute and State University, \\ Blacksburg, VA 24061
}

Additional index words. Asteraceae, tickseed, tissue culture, novel variation, herbaceous perennial

\begin{abstract}
Coreopsis species (tickseed) can be regenerated from leaf segments allowing the possibility to exploit somaclonal variation as a means to develop novel phenotypes. We used true leaf explants from in vitro seedlings of perennial $C$. grandiflora (A. Gray) Sherff 'Domino' and 'Sunray' grown on Murashige and Skoog (MS) basal medium. Two of ten seedlings of 'Domino' regenerated freely and others were generally recalcitrant. From these two seedlings, designated $\mathrm{E} 2$ and $\mathrm{H} 2$, shoots were regenerated and acclimatized to the greenhouse. About 175 plants were established and vernalized from which somaclones were selected based on distinct differences in flower orientation and appearance. The selected somaclones were propagated by division and transplanted to the field in August 2001 in a randomized complete block design with three-plant plots and three replications to determine whether novel characteristics persisted through an additional propagation cycle. In the field, plant height, leaf dimension, flowering, and flower dimensions were scored in June and July 2003. Differences were found between somaclones and similarly propagated E2 and $\mathrm{H} 2$ for desirable (more petals per flower, greater flowering, shorter plants), undesirable (less flowering, smaller flowers), and neutral (narrower leaves, taller plants) traits. Open-pollinated (OP) seed was collected and germinated and the seedlings from somaclones that differed significantly from $\mathrm{E} 2$ and $\mathrm{H} 2$ were evaluated. These maternally selected seedlings were overwintered then planted in the field in May 2004. Most traits that differentiated somaclones from $\mathrm{E} 2$ and $\mathrm{H} 2$ did not persist in the OP seedling population; however variation that was likely introduced through outcrossing resulted in desirable phenotypes with potential for new cultivar development.
\end{abstract}

The Coreopsis genus of the Asteraceae family includes both annual and perennial species. Perennial Coreopsis taxa consistently rank in the top five herbaceous perennials in wholesale value (Behe et al., 2001). The most widely grown cultivars are those of $C$. verticillata L., C. grandiflora (A. Gray) Sherff, $C$. lanceolata L., and hybrids between the latter two species.

Coreopsis is propagated mainly by seed or vegetative crown division. Little information exists on genetic manipulation of the genus for desirable plant characteristics. Introduction of new variability into species of Coreopsis for improvement (flowering, disease resistance, and plant height) is difficult due to the arrangement of florets in the composite flower structure. The flowers within the composite are too small to emasculate single florets, therefore crossing is done by isolating buds, pollinating stigmas at anthesis, and depending on self-incompatibility to prevent selfing (Smith, 1982).

Received for publication 8 Dec. 2005. Accepted for publication 23 Jan. 2006. The authors gratefully acknowledge the assistance of Suzanne Piovano, Velva Groover, Norman Barclift, and Cate Prestowitz. Funding from The Virginia Nursery and Landscape Association Horticultural Research Foundation, the Multicultural Academic Opportunities Program (MAOP) at Virginia Tech and the Institute for Advanced Learning and Research (IALR, Danville, VA) is gratefully acknowledged.

${ }^{1}$ To whom reprint requests should be addressed; e-mail btrader@vt.edu.
In recent years somaclonal variation has been used as a method of introducing variation in ornamental plants. Somaclonal variation has been defined as the genetic change of a plant when regenerated through tissue culture. Mechanisms, molecular analysis, and use of somaclonal variation have been reviewed by Veilleux and Johnson (1998). The use of somaclonal variation for crop improvement has also been investigated and summarized by Karp (1995) and Jain (2001). The benefits of somaclonal variation in improvement of sunflower (Helianthus annuus L.) (Encheva et al., 2003), chili pepper (Capsicum annuum L.) (Houssain et al., 2003), and rose-scented geranium (Pelargonium graveolens L. Herit.) (Ravindra et al., 2004) have been reported. In these studies selected somaclones were found to be horticulturally more desirable than the explant source. Riseman and Chennareddy (2004) investigated the effect of growth regulator regimen on Exacum L. in tissue culture and found that different regimes caused genotypic variation in the form of varied ploidy levels. Cammareri et al. (2002) detected somaclonal variation (capitulum and disk diameter, ligulate flower number) in Aster cordifolius L. 'White Elegans' regenerated from leaf explants. The somaclonal variation described for Aster may be applied to Coreopsis, through a protocol established by Lee et al. (1994) using leaf explants. The objectives of this study were to evaluate Coreopsis somaclones, and investigate the persistence of somaclonal variation through vegetative and sexual reproductive cycles.

\section{Materials and Methods}

Tissue culture. Seeds of C. grandiflora cvs. Domino and Sunray were obtained from Jelitto Seeds, Schwarmstedt, Germany and surface sterilized in full strength commercial bleach containing Tween 20 (Sigma, St. Louis, Mo.) for $20 \mathrm{~min}$ followed by three rinses in sterile distilled water. The disinfected seeds (ten per cultivar) were placed on MS (Murashige and Skoog, 1962) basal medium with 3\% sucrose and $0.7 \%$ agar in $15 \times 150 \mathrm{~mm}$ culture tubes and held in a incubator (16-h photoperiod, 22 to $28 \mu \mathrm{mol} \cdot \mathrm{m}^{-2} \cdot \mathrm{s}^{-1}, 2{ }^{\circ} \mathrm{C}$ ) for germination. True leaf explants were excised from seedlings 2 to 4 weeks after germination. Explants were treated overnight with a liquid pulse treatment [MS containing $54 \mu \mathrm{m}$ naphthaleneacetic acid (NAA) and $44 \mu \mathrm{m}$ benzyladenine (BA)] (Hulme et al., 1992). The explants were then cut in half transversely and placed in $15 \times 100$ $\mathrm{mm}$ petri plates (10 explants per plate) with 20 $\mathrm{mL}$ solid regeneration medium that had been autoclaved for $20 \mathrm{~min}$ at $1.1 \mathrm{~kg} \cdot \mathrm{cm}^{-2}$, containing MS basal salts, $30 \mathrm{~g} \cdot \mathrm{L}^{-1}$ sucrose, $10 \mu \mathrm{M}$ $\mathrm{BA}, 14 \mu \mathrm{M}$ gibberellic acid $\left(\mathrm{GA}_{3}\right)$, and $7 \mathrm{~g} \cdot \mathrm{L}^{-1}$ Phytagar (Gibco, Grand Island, N.Y.). Callus and regenerating explants were transferred to fresh medium every 3 weeks. Regenerated shoots were placed on $1 / 2$-strength MS basal medium with $7 \mathrm{~g} \cdot \mathrm{L}^{-1}$ Phytagar supplemented with $1.5 \%$ sucrose.

Greenhouse methods. Resultant plantlets from two readily regenerating seedlings (E2 and H2) of C. grandiflora 'Domino' were transferred to the greenhouse in December 2000, where they were acclimatized under $50 \%$ shade for 2 weeks. The plants were transferred to $15.2 \mathrm{~cm}$ square plastic pots and grown for 4 weeks without shade. Following acclimation, plantlets were transferred to a bench under fluorescent lights (12-h photoperiod, 22 to 28 $\left.\mu \mathrm{mol} \cdot \mathrm{m}^{-2} \cdot \mathrm{s}^{-1}\right)$ in a walk-in cooler at $4{ }^{\circ} \mathrm{C}$ for vernalization for $16 \mathrm{wks}$. After vernalization, plants were transferred back to the greenhouse for identification of floral and morphological characteristics. During the spring and summer of 2001, floral characters, plant height, and plant vigor of regenerated plants were evaluated to select possible somaclonal variants.

Field methods. Based upon differences in flower form and plant morphology, we selected interesting somaclones in the greenhouse trial and vegetatively propagated them by division in June 2001. The somaclones and the original seedlings (E2 and H2) from which the somaclones derived were planted in the field from vegetative propagules at the Department of Horticulture's Urban Horticulture Center in August 2001 with three replications of three-plant plots to determine whether novel characteristics persisted through a vegetative propagation cycle. Seedlings of C. grandiflora 'Sunray' were also incorporated into the randomized field plots for comparison. Due to a poor field season in 2002, with heavy rain throughout the summer, the plants flowered poorly and the data were not used. Data were 
Table 1. Somaclones $(n=15)$ selected in the greenhouse among 175 first generation tissue culture-derived-plants regenerated from leaf explants of two seedlings (E2 and H2) of Coreopsis grandiflora 'Domino' and the characters for which they were selected.

\begin{tabular}{ll}
\hline $\begin{array}{l}\text { Somaclonal } \\
\text { selection }\end{array}$ & $\begin{array}{l}\text { Distinguishing } \\
\text { characteristics }\end{array}$ \\
\hline E2-1 & Compact habit, small flowers \\
E2-2 & Uniformity of peduncle length, flat corolla \\
E2-6 & Separation of ray flowers, stellate corolla \\
E2-26 & Small flowers, tiered flowering \\
E2-27 & Floriferous, synchronous blooming \\
E2-37 & Flat, open flowers \\
E2-47 & Small flowers, double ray flowers \\
E2-65 & Compact, prostrate, small flowers \\
H2-4 & Mutant, upright ray flowers \\
H2-33 & Incised ray petals \\
H2-42 & Cup-shaped flowers, pale red center \\
H2-43 & Short, compact habit \\
H2-45 & Many ray flowers \\
H2-48 & Many ray flowers \\
H2-49 & Flat, large ray flowers
\end{tabular}

taken on plant height (soil surface to tip of vegetation), leaf dimension, flower diameter, flower stem length (length of flowering stem from soil surface), flowering rate $(0=$ no flowers, $5=$ showy flowers) and flowerpetal number in the field in June 2003. After open-pollination, seeds were collected from plants in each of the three replications of the 12 somaclones that differed significantly from the original seedling clones for at least one character. Likewise, seeds were collected from plants in $\mathrm{E} 2$ and $\mathrm{H} 2$ plots. These seeds were germinated in the greenhouse during Fall 2003 and the progeny of the maternally selected somaclones planted in $15.2-\mathrm{cm}$ square plastic pots and over-wintered in a cold-frame. In May 2004, the seedling families were planted in the field in a randomized complete block design with four replications of three seedlings per plot. In July 2004, data on plant height, leaf dimension, flower diameter, flower stem length, flowering rate, and flower petal number were taken on the maternally selected somaclones.

Statistical analysis. The effects of genotype and replication were analyzed by the GLM procedure of SAS (SAS Institute, 1997) with mean separation by Ryan-Einot-Gabriel-Welsch Multiple Range Test (REGWQ, $\alpha=0.05$ ) for data on plant height, leaf dimension, flower diameter, flower stem length, flower rate, and flower petal number in both field studies.

\section{Results}

In total, 175 somaclones were regenerated from leaves of two seedlings, designated $\mathrm{E} 2$ and $\mathrm{H} 2$, of C. grandiflora 'Domino'. After acclimatization and vernalization, the somaclones flowered and developed over several months in the greenhouse. Collection of data on flower and plant characteristics was not uniform due to lack of coordinated development among the somaclones and a prolonged flowering season. From the 175 somaclones, eight E2 and seven $\mathrm{H} 2$ somaclones were selected for propagation based upon unusual floral characteristics, plant morphology, or growth habit (Table 1 and Fig. 1).

In the first replicated field study, five of

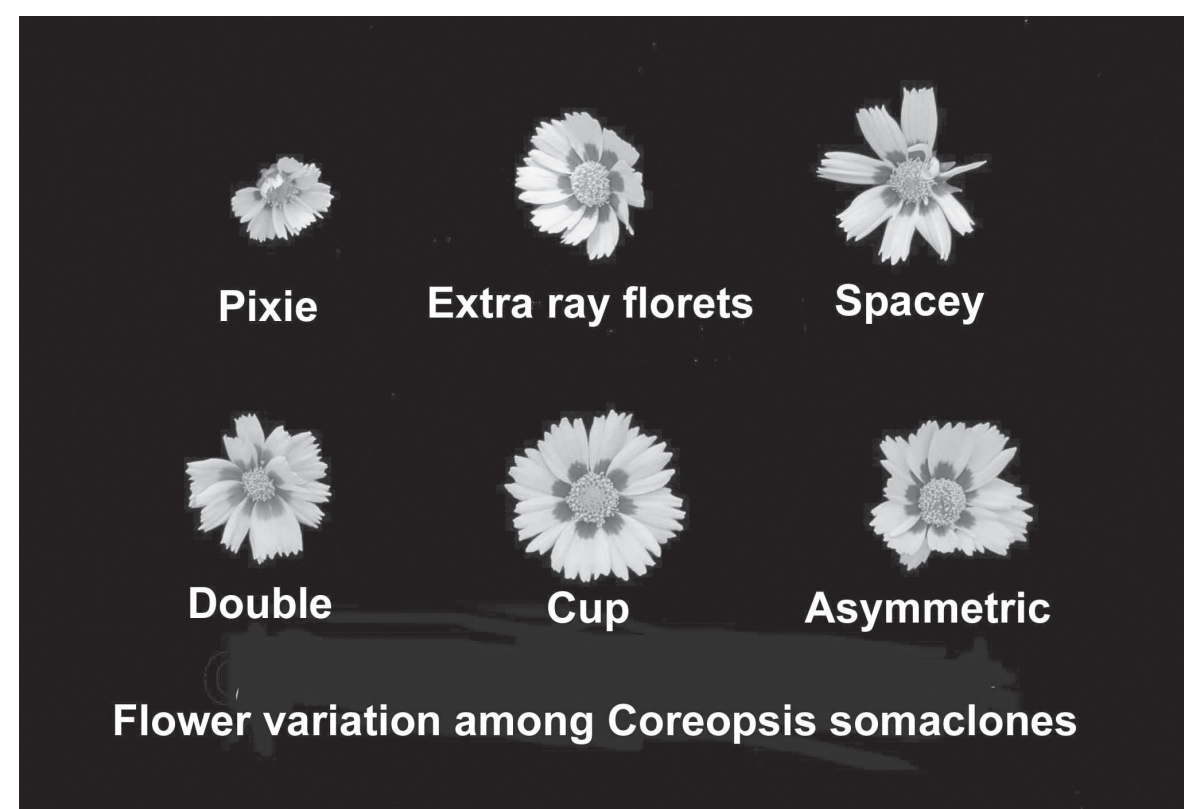

Fig. 1. Variation in rays of flowers from somaclones derived from Coreopsis grandiflora 'Domino'.

eight E2 somaclones (Table 2) and all seven of the $\mathrm{H} 2$ somaclones (Table 3 ) retained at least one character that differed significantly from those of E2 or H2, respectively, such as plant height, leaf ratio, petal number, flower stem length, flower rate, or flower diameter. Some of the somaclones differed from the source plant for three different characteristics, e.g., clone E2-47 (Table 2) and clones H2-49 and H2-43 (Table 3).

The second replicated field study, comprised of seedlings of maternally selected 'Domino' somaclones as well as seedlings of the clonally propagated explant source plants (E2 and H2), from the first field study, revealed novel plant variation for cv. Domino. A likely source of this variation is the self-incompatible nature of Coreopsis (Smith, 1982) and random outcrossing of the somaclones and source plants with seedlings of $C$. grandiflora 'Sunray' also planted within the first field study. Three of the seedling families of maternally selected somaclones differed from seedling families derived from the respective somaclone source (E2 or H2) in one character. Specifically, E247 seedlings were taller than E2 seedlings (26 and $21 \mathrm{~cm}$, respectively), H2-48 seedlings were shorter than $\mathrm{H} 2$ seedlings ( 20 and $26 \mathrm{~cm}$, respectively) and flowers of $\mathrm{H} 2-45$ seedlings were borne on shorter stems than those of H2 seedlings (28 and $35 \mathrm{~cm}$, respectively). Of these three significant differences (among 90 comparisons: 15 seedling families by 6 characters), the only persistent change that reflected a difference found in the first field study between a clonally propagated source plant and its clonally propagated somaclone was the flower stem length of H2-45. New variation was observed in individual plants within the seedling families. This new variation was uncharacteristic of 'Domino' and may be horticulturally desirable, e.g., dwarfism, whorled ray flowers, double ray flowers, absence of red within the center of the corolla and unusual flower structure (Figs. 2 and 3).

\section{Discussion}

Two of ten seedlings of $C$. grandiflora 'Domino' regenerated readily. Evans and Sharp (1986) state that genotype is an important variable when investigating the frequency of regeneration and somaclonal variation in tissue culture. Chloroplast DNA haplotype variation within populations of C. grandiflora was found to be diverse (Mason-Gamer et al., 1995) so differences among regeneration in the genus could be expected. Differences in alleles associated with efficiency of conversion of nitrate to ammonium of a NiR gene in rice have recently been shown to directly affect shoot regeneration potential in tissue culture (Nishimura et al., 2005).

Somaclones of Coreopsis grandiflora 'Domino' that were selected in the greenhouse as possibly interesting horticultural variants had characteristics such as dwarf habit, unusual leaf and flower morphology, and number variation for floral rays. These characteristics were

Table 2. Means for height, leaf ratio, petal number and flower rate of the source plant for explants (E2 Control) and five E2 somaclones initially selected in the greenhouse and then propagated vegetatively and planted in the field. Means represent nine plants of each somaclone from three-plant plots in three replications of a randomized complete block design planted in August 2001. Data were recorded during Spring and Summer 2003.

\begin{tabular}{lcccc}
\hline & $\begin{array}{c}\text { Plant } \\
\text { ht } \\
(\mathrm{cm})\end{array}$ & $\begin{array}{c}\text { Leaf } \\
\text { ratio }\end{array}$ & $\begin{array}{c}\text { Petal } \\
\text { no. }\end{array}$ & $\begin{array}{c}\text { Flower } \\
\text { rate }\end{array}$ \\
\hline E2 control & $39 \mathrm{a}^{\mathrm{z}}$ & $5.6 \mathrm{~b}$ & $8.1 \mathrm{c}$ & $2.3 \mathrm{~b}$ \\
E2-6 & $31 \mathrm{ab}$ & $6.5 \mathrm{~b}$ & $10.0 \mathrm{a}$ & $2.4 \mathrm{~b}$ \\
E2-26 & $28 \mathrm{~b}$ & $6.3 \mathrm{~b}$ & $8.7 \mathrm{abc}$ & $2.4 \mathrm{~b}$ \\
E2-37 & $27 \mathrm{~b}$ & $6.0 \mathrm{~b}$ & $9.8 \mathrm{abc}$ & $2.2 \mathrm{~b}$ \\
E2-47 & $14 \mathrm{c}$ & $10.3 \mathrm{a}$ & $8.3 \mathrm{bc}$ & $4.7 \mathrm{a}$ \\
E2-65 & $24 \mathrm{~b}$ & $6.3 \mathrm{~b}$ & $9.6 \mathrm{abc}$ & $2.6 \mathrm{~b}$ \\
\hline
\end{tabular}

${ }^{\mathrm{z}}$ Means followed by the same letter do not differ at the 0.05 significance level within the column by REGWQ test. 
Table 3. Means for leaf ratio, flower stem length, flower diameter, petal number and flower rate of the source plant for explants (H2 control) and seven $\mathrm{H} 2$ somaclones initially selected in the greenhouse and then propagated vegetatively and planted in the field. Means represent nine plants of each somaclone from three-plant plots in three replications of a randomized complete block design planted in August 2001. Data were recorded during Spring and Summer 2003.

\begin{tabular}{|c|c|c|c|c|c|}
\hline Clone & $\begin{array}{l}\text { Leaf } \\
\text { ratio }\end{array}$ & $\begin{array}{l}\text { Flower } \\
\text { stem } \\
\text { length } \\
(\mathrm{cm})\end{array}$ & $\begin{array}{c}\text { Flower } \\
\text { diam } \\
(\mathrm{cm})\end{array}$ & $\begin{array}{c}\text { Petal } \\
\text { no. }\end{array}$ & $\begin{array}{c}\text { Flower } \\
\text { rate }\end{array}$ \\
\hline$\overline{\mathrm{H} 2 \text { control }}$ & $4.9 c^{z}$ & $42 \mathrm{~b}$ & $7.5 \mathrm{a}$ & $7.7 \mathrm{c}$ & $3.8 \mathrm{a}$ \\
\hline $\mathrm{H} 2-4$ & $5.2 \mathrm{bc}$ & $51 \mathrm{ab}$ & $4.9 \mathrm{ab}$ & $9.6 \mathrm{~b}$ & $2.8 \mathrm{ab}$ \\
\hline $\mathrm{H} 2-33$ & $6.0 \mathrm{ab}$ & $49 \mathrm{ab}$ & $4.8 \mathrm{ab}$ & $9.6 \mathrm{~b}$ & $2.6 \mathrm{ab}$ \\
\hline $\mathrm{H} 2-42$ & $5.3 \mathrm{bc}$ & $45 \mathrm{ab}$ & $4.4 \mathrm{~b}$ & $8.6 \mathrm{bc}$ & $2.9 \mathrm{ab}$ \\
\hline $\mathrm{H} 2-43$ & $5.6 \mathrm{bc}$ & $52 \mathrm{a}$ & $4.9 \mathrm{ab}$ & $9.3 \mathrm{~b}$ & $1.8 \mathrm{~b}$ \\
\hline $\mathrm{H} 2-45$ & $5.4 \mathrm{bc}$ & $51 \mathrm{ab}$ & $5.0 \mathrm{ab}$ & $8.9 \mathrm{bc}$ & $2.0 \mathrm{~b}$ \\
\hline $\mathrm{H} 2-48$ & $5.1 \mathrm{c}$ & $43 \mathrm{ab}$ & $4.4 \mathrm{~b}$ & $10.9 \mathrm{a}$ & $2.7 \mathrm{ab}$ \\
\hline H2-49 & $6.5 \mathrm{ab}$ & $52 \mathrm{a}$ & $5.1 \mathrm{ab}$ & $9.0 \mathrm{bc}$ & $2.1 \mathrm{~b}$ \\
\hline
\end{tabular}

${ }^{\mathrm{z}}$ Means followed by the same letter do not differ at the 0.05 significance level within the column by REGWQ test.

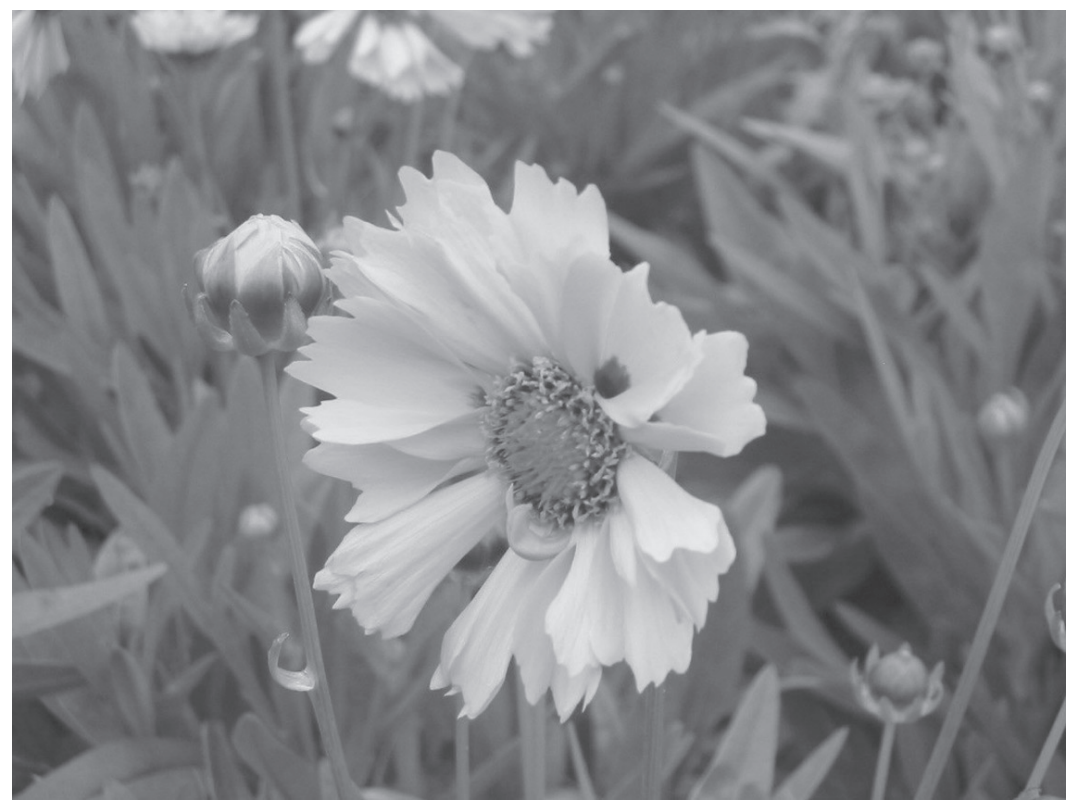

Fig. 2. Presence of tubular ray florets from maternally selected somaclones of Coreopsis grandiflora in 2004.

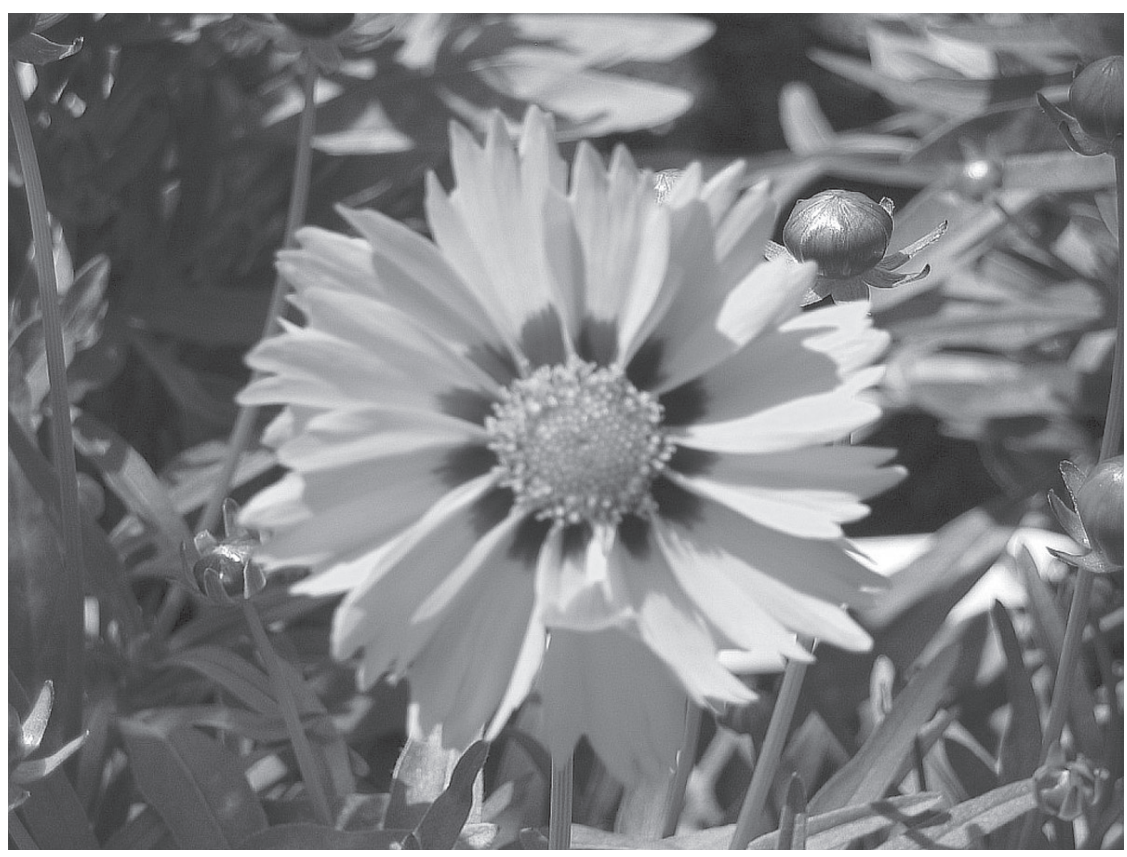

Fig. 3. Presence of doubled rays from maternally selected somaclones of Coreopsis grandiflora in 2004. persistent through vegetative reproduction in field trials of most of the selected somaclones (Tables 2 and 3). Somaclonal variants of Chrysanthemum L. described by Chang et al. (2000) also differed from source plants for similar traits including plant height, stem internode length, and number of disc and ray flowers. The trend of somaclonal variants to differ with respect to height, plant form, and number of plant floral or stem structures has been discussed with regard to two species of Picea Link. (Tremblay et al., 1999). 'Velvet Rose' Pelargonium, characterized by large trichomes and glands, dense pubescence, and thick leaves was the first tissue-culture derived cultivar released (Skirvin and Janick, 1976a). In a study conducted by Skirvin and Janick (1976b), calliclones or clonal variants originating from callus tissue, differed from original explant sources with changes in plant and organ size, leaf and flower morphology and other characters such as pigmentation.

Persistence of somaclonal variation through a sexual cycle is generally taken as evidence of true genetic change (Veilleux and Johnson, 1998). In the case of Coreopsis, a cross-pollinating and self-incompatible species, our effort to determine the persistence of somaclonal variation in sexually derived seedlings after the initial somaclonal variants were characterized in the field was compromised by outcrossing with another cultivar. Smith (1982) and Archibald et al. (2005) have noted the reproductive isolation of perennial Coreopsis and that hybridization between perennial species and cultivars resulted in fertile hybrids. Only dominant mutations would be expected to persist after outcrossing. Other sources of somaclonal variation such as chromosome rearrangements, ploidy variation or recessive mutations would be obscured.

Although somaclonal variation for morphological characters has been reported for ornamentals (Buiatti and Gimelli, 1993), utilization of somaclonal variation for crop improvement has been concentrated on food and grain crops. A few ornamental cultivars have been introduced as a result of somaclonal variation, such as Hemerocallis spp. L. (Griesbach, 1989) and Torenia foumieri L. (Brand and Bridgen, 1989). Other horticultural cultivars derived from tissue culture via somaclonal variation have been summarized by Skirvin et al. (1994). Future research will focus on evaluation of our selected Coreopsis somaclones with unique characters (dwarf plants, plants with tubular ray flowers, plants with double ray flowers, and unusual flower structure) for their stability and cultivar potential.

\section{Literature Cited}

Archibald, J.K., M.E. Mort, D.J. Crawford, and J.K. Kelly. 2005. Life history affects the evolution of reproductive isolation among species of Coreopsis (Asteraceae). Evolution 59:2362-2369.

Behe, B., K. Kelley, J. Heilig, and R. Walden. 2001. Survey of annuals and perennials. Proc. S. Nurs. Assn. 46:556-562.

Brand, A.J. and M.P. Bridgen. 1989. "Uconn White': A white-flowered Toreniafournieri. HortScience 24:714-715. 
Buiatti, M. and F. Gimelli. 1993. Somaclonal variation in ornamentals, p. 5-24. In: T. Schiva and A. Mercuri (eds.). Creating genetic variation in ornamentals. Proc. 27th Symp. Euro. Assn. Res. Plant Breed., EUCARPIA, Sanremo, Italy, 1-5 Mar. 1993.

Cammareri, M.,A. Errico, E. Filippone, S. Esposito, and C. Conicella. 2002. Induction of variability in chimeric Aster cordifolius 'White Elegans' through somaclonal variation. Euphytica 128:19-25.

Chang, S.F., M.C. Huang, S.F. Chang, and M.C. Huang. 2000. The variation in tissue culturederived plants of Chrysanthemum. J. Chinese Soc. Hort. Sci. 46:21-34.

Encheva, J., H. Kohler, W. Friedt, F. Tsvetkova, P. Ivanov, V. Encheva, and P. Shindrova. 2003. Field evaluation of somaclonal variation in sunflower (Helianthus annuus L.) and its application for crop improvement. Euphytica 130:167-175.

Evans, D.A. and W.R. Sharp. 1986. Somaclonal and gametoclonal variation, p. 97-132. In: D.A. Evans, W.R. Sharp, and P.V. Ammirato (eds.). Handbook of plant cell culture. vol. 4. Techniques and application. Macmillan, New York.

Griesbach, R.J. 1989. Selection of a dwarf Hemerocallis through tissue culture. HortScience 24:1027-1028.

Houssain, M.A., K. Konisho, M. Minami, and K. Nemoto. 2003. Somaclonal variation in regenerated plants in chili pepper (Capsicum annuиm
L.). Euphytica 130:233-239.

Hulme, J.S., E.S. Higgins, and R. Shileds. 1992. An efficient genotype-independent method for regeneration of potato plants from leaf tissue. Plant Cell Tiss. Org. Cult. 31:161-167.

Jain, S.M. 2001. Tissue culture-derived variation in crop improvement. Euphytica 118:153-166.

Karp, A. 1995. Somaclonal variation as a tool for crop improvement. Euphytica 85:295-302.

Lee, C.W., J.T. Nichols, L. Wang, and S. Ke. 1994. Plant regeneration in Coreopsis lanceolata L. from leaf tissue cultures. HortScience 29:1353-1354.

Mason-Gamer, R.J., K.E. Holsinger, and R.K. Jansen. 1995. Chloroplast DNA haplotype variation within and among populations of Coreopsis grandiflora (Asteraceae). Mol. Biol. Evol. 12:371-381.

Murashige, T. and F. Skoog. 1962. Arevised medium for rapid growth and bioassays with tobacco tissue cultures. Physiol. Plant 15:473-497.

Nishimura, A., M. Ashikari, S. Lin, T. Takashi, E. Angeles, T. Yamamoto, and M. Matsuoka. 2005. Isolation of a rice regeneration quantitative trait loci gene and its implication to transformation systems. Proc. Natl. Acad. Sci. 102:11940-11944.

Ravindra, N.S., R.N. Kulkarni, M.C. Gayathri, and S. Ramesh. 2004. Somaclonal variation for some morphological traits, herb yield, essential oil content, and essential oil composition in an
Indian cultivar of rose-scented geranium. Plant Breed. 123:84-86.

Riseman, A and S. Chennareddy. 2004. Genotypic variation in the micropropagation of Sri Lankan Exacum hybrids. J. Amer. Soc. Hort. Sci. 129:698-703.

SAS Institute. 1997. SAS guide for personal computers, version 6.12. SAS Inst, Cary, N.C.

Skirvin, R.M. and J. Janick. 1976a. 'Velvet Rose' Pelargonium, a scented geranium. HortScience 11:61-62.

Skirvin, R.M. and J. Janick. 1976b. Tissue cultureinduced variation in scented Pelargonium spp. J. Amer. Soc. Hort. Sci. 101:281-290.

Skirvin, R.M., K.D. McPheeters, and M. Norton. 1994. Sources and frequency of somaclonal variation. HortScience 29:1232-1237.

Smith, E.B. 1982. Phyletic trends in section Coreopsis of the genus Coreopsis (Compositae). Bot. Gaz. 143:121-124.

Tremblay, L., C. Levasseur, and F.M. Tremblay. 1999. Frequency of somaclonal variation in plants of black spruce (Picea mariana, Pinaceae) and white spruce ( $P$. glauca, Pinaceae) derived from somatic embryogenesis and identification of some factors in genetic instability. Amer. J. Bot. 86:1373-1381.

Veilleux, R.E. and A.A.T.Johnson. 1998. Somaclonal variation: molecular analysis, transformation interaction, and utilization. Plant Breed. Rev. 16:229-268. 